\title{
Relation between the Constitution of the Republic of Azerbaijan and International Legal Acts in the Sphere of Human Rights
}

\author{
Sona Huseyn Galandarli ${ }^{1}$ \\ ${ }^{1}$ Faculty of Law, Doctoral candidate of Constitutional Law Department, Baku State University, Azerbaijan \\ Correspondence: Sona Huseyn Galandarli, Faculty of Law, Doctoral candidate of Constitutional Law \\ Department, Baku State University, Azerbaijan. E-mail: sgalandarli@mail.ru
}

\author{
Received: May 19, 2013 Accepted: June 23, 2013 Online Published: September 29, 2013 \\ doi:10.5539/ass.v9n13p105 URL: http://dx.doi.org/10.5539/ass.v9n13p105
}

\begin{abstract}
The article gives wide information about the relationship between the Constitution of the Azerbaijan Republic and international legislation in the field of human rights. The author shows that Universal Declaration of Human rights is a basic international legal document used in the constitutional construction. It served as an example for the constitutions of many states of the world community. Along with the national, moral and ethic values, the Constitution of the Republic of Azerbaijan co-opted national and universal human priorities.
\end{abstract}

Keywords: international law, human rights, national legal systems, constitution

\section{Introduction}

The purpose of this paper is to investigate the impact of international human rights law on the formation of national human rights institutions in the constitutional law. This material is only part of a comprehensive comparative analytical research into the interaction of international law and national industries, which includes a wide range of issues and legal loopholes. The object of research is the level of influence of international legal instruments in the field of human rights at the national human rights institutions, the structure and practice of implementation, including the law-making and law enforcement (legal acts, executing agencies, etc.). In the methodological basis of this paper have been put global values associated with the legal status of a person, international legal acts in the field of human rights, constitution, national legislation in this area. During the survey used a method of comparative law analysis.

List and characteristics of the human rights enshrined in international instruments are not unconditional and comprehensive for each state. National legislation providing for its citizens rights, which are defined by the nature of the social system, the level of economic and social development, historical and cultural traditions, moral and ethical characteristics, especially on the major bioethical issues today. The modern legislation the independent Republic of Azerbaijan in the sphere of human rights protection is formed in accordance with international guidelines and taking into consideration national peculiarities and cultural diversity of the peoples residing in the country.

The main part is assigned to Constitutions in the determination of interaction of the national law and international statutory acts. Modern processes of globalization in all the spheres of vital activity of states, strengthening of international relations, and integration of the world community facilitate the establishment of general democratic principles in constitutional construction. The priority status of international legal acts within the internal legislation becomes an objective necessity.

The tendency of the mutual approach of national and international law has widely developed. At the same time, the problem of preservation of states' sovereignty both in a constitutional and an international legal context is topical. That's why the above-mentioned approach takes place not as a simple replacement of one law by another, but by a number of such legal mechanisms as implementation, transformation, etc. The well-known legal scholar R. Mullerson calls implementation of international law standards to be the most important method of their realization on the national level (Mullerson, 1980). These mechanisms provide an independent status of the state as a principal subject of legal relations and reflect its primary role. First of all, the state as a rule-proclaiming subject is vested with the function of supporting the implementation of international law standards within the country. 
As international law demanded by objective conditions of the existent globalization is progressively developing, the amount of international statutory acts, covenants and agreements continuously grows. Such fundamental documents as declarations, conventions and protocols in the sphere of protection of human rights and freedoms constitute a considerable specific gravity among them. Practically, all the states by means of their legislative practice actively implement standards of international law, such as the Universal Declaration of Human Rights, the European Convention on the Protection of Human Rights and Fundamental Freedoms and many others. (http://www.memo.ru/prawo/euro/eucnv.htm)

\section{International Legal Acts in the Sphere of Human Rights}

The Universal Declaration of Human Rights adopted by the UN General Assembly (in 1948) is of a considerable importance in law-making of subjects of international law ("Bioethics: documents, terms" Baku, 2009, p.12-18). The provisions of the Declaration became an integral part of national constitutions, legislative acts of states. Its recognition and ratification define a state as a democratic one with the developed legal system. Under current conditions when the world becomes more interrelated, information and social networks covered all the outer space, people can freely cross administrative and state borders and bring their own intellectual values, traditions and way of life, it is human rights and the degree of their observance that become an indicator of democratic development of the state. In terms of law, politics and morality under the conditions of globalization, the Universal Declaration is more significant these days than it was at the moment it was adopted more than fifty years ago.

The international community has scored major successes in the elaboration of universal standards in the sphere of human rights and numerous mechanisms for their application and realization. Meanwhile, even at the highest effectiveness of international mechanisms, a prime responsibility for ensuring human rights is borne by national governments and their ability to provide a maximum compliance of constitution and internal legislation with the provisions of the Universal Declaration and other international legal acts and standards.

As a general international treaty, one can mention Vienna Convention on the Law of Treaties 1969. Part III of the Convention "Observance, Application and Interpretation of Treaties" provides for the principle "pacta sunt servanda" (Article 26) which directly states that "Every treaty in force is binding upon the parties to it and must be performed by them in good faith" and further - "A party to any treaty "may not invoke the provisions of its internal law as justification for its failure to perform a treaty" (Article 27). It is this provision that is recognized as one of the factors that internal law must conform to international law (http://www.referent.ru/1/42195). In other words, the state must build its legal system so that it did not contradict international standards and acts, but conformed to them. This provision is also acknowledged in many treaties between the states where the latter undertake to bring their national law to conformity with the treaty. For example, paragraph 1 of Article 2 of the International Covenant on Economic, Social and Cultural Rights 1966 says: "Each State Party to the present Covenant undertakes to take steps, individually and through international assistance and co-operation, especially economic and technical, to the maximum of its available resources, with a view to achieving progressively the full realization of the rights recognized in the present Covenant by all appropriate means, including particularly the adoption of legislative measures" (http://un.org/documents/decl_conv/conventions/pactpol/shtml).

The International Covenant on Civil and Political Rights adopted in the same year specifies that if the rights recognized in the present Covenant are not provided for "by existing legislative or other measures, each State Party to the present Covenant undertakes to take necessary steps, in accordance with its constitutional processes and with the provisions of the present Covenant, to adopt such laws or other measures as may be necessary to give effect to the rights recognized in the present Covenant" (paragraph 2, Article 2) (http://un.org/documents/decl_conv/conventions/pactpol/shtml). As regards the position of internal legal systems it can be noted that the internal action of international law standards is recognized in the overwhelming majority of constitutions adopted after World War II. When adopting any legislative act within the internal legislative process, in the first place, an attention is paid to their compliance to international law.

Through the decades since the adoption of the UDHR it seemed that the world had adopted a unified approach to the concept of human rights and recognized the importance of it. However, the recent changes affecting the modern world, the threat of terrorism, globalization and fear of the loss of identity have re-opened the discussion on the universality of human rights and put into question the importance and the role of regional human rights systems (Vitkauskaite-Meurice, 2010).

\subsection{Human Rights in the National Legal Systems}

The modern globalizing world community puts forward new demands to national legal systems, including constitutional construction. Today every country has a unique chance to make a legal protection of every citizen 
to be a peculiarity of its changed society. The indicator of protection of civil rights and freedoms in one or another state ranks with such characteristics as level of economic state, political stability, and potential of intellectual, producing and raw material capacities. A human being, its needs and protection of rights come to the foreground in a society that links its future with not the receipt of dividends out of natural resources, but gives preference to a human factor. No doubt, a modern approach to human rights must be provided for by the constitution and conform to international legal norms. With all the universality of concept of human rights that enhances more and more in the worldwide globalization, nevertheless, the sphere of human rights is governed by the constitution of the specific state, and their protection guaranteed exclusively by the internal law and order. Like economy, culture, etc., human rights originate in already well-established way of life, national traditions. It is impossible to suddenly adopt them to something strange, even if it's the best. Human rights are a triad of interrelations: human being - society - state. To make international universal human rights to be private and consistent to a national sprit of a nation, society and state is a complex, but a realizable task.

Human rights and their provision is a measure of democracy level of society, and the Universal Declaration is a basic international legal document in constitutional construction. It served as an example for the constitutions of many countries in the world community. As a global source of standards of human rights, the Declaration has a binding force for all the states that have recognized it. Its provisions are directly or indirectly included in the text of the constitutions in the national law of many countries. For example, the articles regarding human rights constitute a third of all the provisions of the Constitution of the Republic of Azerbaijan (47 out of 158 articles). At the same time, a high efficiency of international mechanisms does not replace a proper responsibility of national constitutions and internal law-enforcement practice for observance of human rights. International treaties facilitate a continuous expansion of human rights declared by the constitution, as well as improvement of mechanisms of their warranties. At the same time, new democratic institutions and structures also develop. International legal acts, standards, and treaties regarding the protection of human rights today are ratified by the overwhelming majority of countries, such documents numbers more than a thousand. The degree of influence of ratified treaties on the national legislative base and constitutional law of various states is different.

As a full independent member of the world community with the developed political and economic system, the Republic of Azerbaijan joined many universal agreements where international standards of human rights are stated, such as International Covenant on Civil and Political Human Rights, 1966 and International Covenant on Social and Cultural Rights (both covenants are ratified in 1992); UN Convention on the Rights of the Child 1989 (ratified in 1992) (Official reports of the UN General Assembly, session 44); UN Convention on the Political Rights of Women, 1952 (ratified in 1992); and UN Convention on the Elimination of All Forms of Discrimination against Women, 1979 (ratified in 1995) (Official reports of the UN General Assembly, session 34); International Convention on the Elimination of All Forms of Racial Discrimination, 1965 (ratified in 1996) (United Nations Treaty Series, vol. 660); International Convention on the Suppression and Punishment of the Crime of Apartheid, 1973 (ratified in 1996) (http://proza.ru/2008/09/30/140); UN Convention on the Prevention and Punishment of the Crime of Genocide, 1948 (ratified in 1996) (http://krotov.info.acts/20/1940/19481209.html); UN Convention against Torture and Other Cruel, Inhuman or Degrading Treatment or Punishment, 1984 (ratified in 1996) (http://www.un.org/Russian/document/convents/torture/html) and many others.

\section{Protection of Human Rights in the National Legal System of the Republic of Azerbaijan}

The Article 12 (Chapter II) of the Constitution of the Republic of Azerbaijan specifies a provision reflecting the protection of human rights: "1.The highest priority objective of the state is to provide rights and liberties of a person and citizen. 2. Rights and liberties of a person and citizen are implemented in accordance with international treaties wherein the Republic of Azerbaijan is one of the parties". The Constitution of the Republic of Azerbaijan contains a double provision of direct action in respect of human rights. According to the Article 147 in Chapter X the basic law "possesses highest legal power and possesses direct legal act". This provision is supplemented by Article 71 in Chapter III which says: "Rights and liberties of a human being and citizen act on the territory of the Republic of Azerbaijan by themselves". Considering the fact that rights and liberties of a human being and citizen are observed in accordance with so named international standards recognized by the republic (Article 12, Chapter II), their direct action within the country become unconditional (Constitution of the Republic of Azerbaijan, 2005). Such a definition in constitutional law makes it possible, as appropriate, for any citizen to apply for and refer to both the constitution and the respective international act in the sphere of human rights. The above-mentioned Article 71 (Chapter III) of the Constitution states the responsibility of the state to provide the protection of rights and liberties: "To observe and to protect rights and liberties of a human being and citizen specified in the Constitution - is responsibility of bodies of legislative, executive and legal power". 
Fundamental international documents on human rights also include "a principle of legality" which reflects an essential condition of legality of restriction of human rights as appropriate. These provisions are included in the Universal Declaration of Human Rights (Article 29), the International Covenant on Civil and Political Rights (Articles 12, 14, 18), European Convention on Human Rights (Articles 8-11) and a number of agreements. According to this principle, Article 71 of the Constitution of the Republic of Azerbaijan says: "Rights and liberties of a human being and citizen may be partially and temporarily restricted...taking into consideration international obligations of the Republic of Azerbaijan".

Some collisions and gaps in law occur in the practice of application of international legal standards in the national constitutional construction. Then the necessity to conform ratified international acts and internal legislative base arises. It occurs differently in various countries, but certainly taking into account national constitutional provisions and peculiarities of legal systems. Individual cases of infringement of human rights are essentially unwanted but in a State respecting the rule of law normally are able to be resolved. The lack of qualified discussion during the limiting of human rights by way of laws and implementing regulations is however a systemic problem. Correction of its results can be often very complex and doing away with the causes a long term effort. It is dependent on the quality of representative democracy and of the civil society as well (Kudrna, 2012).

3.1 The National Program of Actions on the Increase of Effectiveness of Protection of Human Rights and Freedoms in the Republic of Azerbaijan

Further to and in pursuance of international documents in the sphere of human rights, decrees and orders are issued by the President of the Republic of Azerbaijan. Among them the Decree "The National Program of actions on the increase of effectiveness of protection of human rights and freedoms in the Republic of Azerbaijan" of December 27, 2011 which once again provides that the highest goal of the state is to provide rights and freedoms of a human being and citizen specified by the Article 12 of the Constitution (http://ru.president.az/articles/4013). According to this Decree, the protection of human rights in the republic is implemented in the following directions:

I. Development of legal framework

II. Protection of rights of different population groups

III. Improvement of the activities of public authorities

IV. Implementation of academic, research and educational campaign in the sphere of human rights

V. Cooperation with international organizations in the sphere of human rights

VI. Coordination of realization, monitoring and evaluation of the National Program of actions.

The principal mechanism for the realization of the National Program that governs the relation of international and internal standards is the development of the legal framework which presumes the orientation of all the laws adopted in the republic on the unconditional provision of human rights and freedoms specified, firstly, by the Constitution and, secondly, by international agreements wherein the Republic of Azerbaijan is one of the parties. The law-making practice formed in the country supposes the necessity of consultations and expert judgments by international organizations specialized in human rights. Their decision is obligatorily taken into account in the process of work over draft laws and adoption of laws by the parliament. According to the obligations assumed by the Republic of Azerbaijan within the framework of international agreements on human rights and freedoms, the measures on realization of rights protection control, submission of periodic reports by the republic, execution of recommendations and decisions of specialized structures of the United Nations Organization, the Council of Europe, European Court on Human Rights and other international organizations are implemented within the scope of internal jurisdiction. The process of execution of obligations includes execution of the detailed analysis of recommendations and their conformity to the national legislation, determination of set of necessary measures, as well as list of state structures that are responsible for realization.

The national program in the sphere of protection of human rights including other provisions indicates the necessity of supplements and amendments to the Code of Criminal Procedure of the Republic of Azerbaijan which must ensure the legality of holding detainees in custody, and the observance of rights of persons serving sentences in prison. Non-interference in personal life becomes one of the priority human rights under the conditions of information globalization of the world community (Article 32, paragraph 2 of the Constitution of the Republic of Azerbaijan, 2005). For the purpose of increasing the efficiency of struggle with such infringements, the National Program provides for the update of the Chapter "Crime against Computer Information" in the Criminal Code of the Republic of Azerbaijan and its conformation to the requirements of the 
Convention on Cybercrime of November 23, 2001 (Committee on Crime problem, 1990); (UN Documents.144/7, pg.7-8; A/46/346.Add.2, p.2).

The National Program of Actions on the increase of effectiveness of protection of human rights and freedoms approved by the President of the Republic of Azerbaijan covers set of active laws needed an additional update by obligations assumed by the state respectively. It includes prevention of sexual exploitation of children, migration, maternity protection, equal opportunities for working men and women who have family obligations, responsibility and obligations of parents on upbringing of children, rights of refugees and internally displaced persons, ethnic minorities, consumers and manufacturers, immunity of personal property, health and environmental protection, rights of handicapped children and many other legislative acts. The Republic of Azerbaijan carries out necessary measures on the ensuring of rights and freedoms of every citizen, irrespective of his place of residence. To this effect the National Program provides for the conclusion of agreements with foreign states and their authorities to ensure rights of the citizens of the Republic of Azerbaijan living in these states.

Up to date the Republic of Azerbaijan joined a great deal of declarations, conventions and other legal documents of the United Nations Organization, as well as international agreements of various organizations. At the same time, considering a constant development of international law in the sphere of human rights and adoption of new international agreements, it is necessary to carry out analysis whether it is feasible for the Republic of Azerbaijan to join to one or another documents taking into account national peculiarities of the civil society and the legislative base. This important moment is also paid attention to in the National Program.

To build really a legal democratic state, the transparency of activities in all the spheres of the state's activity is required. The increase in the potential of the national mechanisms of anti-corruption, continuation of institutional reforms in this field, efficient relations and collaboration with the specialized international intergovernmental and non-governmental structures - these measures are provided for by the National Program within the framework of various joint programs and projects. Back in 2007 The Action Plan for the implementation of the National Strategy on Increasing Transparency and Anti-Corruption for 2007-2011 was approved by the Decree of the President of the Republic of Azerbaijan (http://07kbr.ru/2012/09/14v-az-usil-bor-s-kor). It is known that a due and exact execution of judgments is a constituent part of the right of persons to justice. The National Program on the protection of human rights includes familiarization of judges, candidate judges, officials of law-enforcement bodies and lawyers with international declarations, conventions and other normative legal documents in the sphere of human rights, and study of international practice in this sphere.

The National Program determines the realization of academic and educational campaign as a priority in the improvement of legal education and legal culture of the civil society. It is necessary to provide for an effective execution of principles declared by the UN General Assembly on the enlightenment and education in the sphere of human rights and recommendations of the Global Instruction Program of the UN Supreme Commissariat on Human Rights (http://www.ohchr/org.rudoks.exdat.com/index-524944.html), UNESCO document Education for Sustainable Development (http://prava.by/unescochairs.sprav.asp). The educational issues of the National Program embraces such measures as design of study guides for higher and high education, reference materials, brochures, placards, and booklets, delivery of split-level trainings for target and non-target audience, training of specialized staff - teachers, researchers and trainees, arrangement of courses and centers for educational activities, Internet-education, use of resources of mass media, television and radio, etc.

In the National Program a great importance is attached to the cooperation with international organizations in the sphere of human rights, preparation and implementation of joint projects with the specialized institutions of the United Nations Organization, international regional organizations, including structures specialized in the sphere of human rights such as UNESCO, UNICEF, the World Bank, as well as Council of Europe, the European Union, the Organization for Security and Cooperation in Europe, the Organization of Islamic Cooperation, etc. The realization of joint projects and programs makes it possible to use an international practice in the process of institutional reforms carried out in the country, and creates opportunities for attracting international specialists to joint developments.

Back in 1995 Azerbaijan started the cooperation with the Council of Europe which resulted in the elaborated Action Plan for 2012-2013 in the judicial and legal sphere, anti-corruption, youth policy, development of civil society, etc.

The activity of Azerbaijan in the field of realization of Millennium Development Goals declared by UNO is also fruitful. In this respect and in pursuance of the stated goals, by his Decree in 2006 the President approved the National Action Plan on the Protection of Human Rights in the Republic of Azerbaijan (http://hrlibrary.ngo.ru/russian/cerd/Rreport_azer.2008.html). For the coordination and evaluation of the actions 
within the National Program, monitoring and preparation of analytical information it is provided to create a working group consisting of representatives of local executive power, municipalities, judicial bodies, bodies of internal affairs and public prosecution offices, non-governmental organizations, mass media, local communities and other structures concerned.

The adopted National Program is a an important element in the system of measures on the building of a legal state, forming of democratic constitutionalism in the country, conformity of the national constitutional and other areas of law with international legal standards and acts in the sphere of rights and freedoms of a human being and citizen. It provides the sustainability of measures directed to increasing of efficiency of rights protection, the development of legal culture in society, and improvement of legal framework and human rights system.

The determinant in constitutional construction of any democratic state is public opinion. The practice of the countries with the developed institutions of constitutionalism shows that the formation of democratic constitutions is possible only provided the voice of the electorate itself (vox poluli) is heard.

The sociological studies carried out in the republic on a regular basis and representative analysis of their results make it possible to define public opinion with regard to the existing constitutionalism in the country and its interaction with international legal acts, treaties, agreements, etc. For example, in mini-inquiry carried out by the author of this thesis, the respondents were asked about the constitutional construction in republic. One of the offered matrixes contained answers to the question on the establishment of the Basic Law in the Republic of Azerbaijan. As it turned out, 31 per cent of respondents think that it was established on the model of constitutions of the advanced democratic states of the world. 36 per cent of the pollees stick to the opinion that the constitution with subsequent amendments adopted in 1995 is a cardinally new one which takes into account the national peculiarities of the development of Azerbaijan society and traditions of mentality. 14 per cent of the pollees are sure the constitution of Azerbaijan is established by using international legal documents, and 5 per cent have chosen the following version of answers offered in the matrix - "The former Constitution of the Soviet Azerbaijan is taken as a basis". A considerable rate of persons who find it difficult to answer is regretful - 14 percent; it talks about still insufficient legal enlightenment of the civil society. In the questionnaire on the use of provisions of international legal documents in the constitution the answers to questions were distributed as follows: "certainly, it is necessary to use them" - 21 per cent of respondents; "they shouldn't be used as the Azerbaijani people have their own national principles and traditions other than the global ones" - 38 per cent of the pollees, and "they should be used, but taking into account the internal legislation" - 40 per cent. These figures indicate a great interest of the population (more than a third of the pollees) in the preservation in the Basic Law of the republic of national peculiarities of mentality and legal traditions established for centuries. At the same time, the Azerbaijani people understand that developing within the world democratic community, integrating into a single political and legal framework, it is impossible to abstract away from world democratic values; it is exactly such an attitude to the national constitutional construction that was expressed by more than a half of respondents in their answers ( 21 plus 40 per cent). The neutrals to this problem turned to be few - only one per cent failed to define their answer. Such is the situation in the republic which with the attainment of independence reached an unprecedented economic prosperity, political stability and establishment of the democratic legal system for a short historical period.

\section{Conclusion}

On the basis of the carried investigation we come to the conclusion that since any modern state lives and develops in the integrate world community practically any area of its activities is connected with international acts and legal standards. Adding them to the national constitutional law is one of the peculiarities of the modern development of constitutional construction. The state expresses its own political will in its decision to accept one or another document for its realization in the internal legislation. It is evident that in such cases the violation of sovereignty does not occur - the state executes international legal standards in accordance with the principles and traditions of its constitutionalism. The Universal Declaration of Human rights is a basic international legal document used in the constitutional construction. It served as an example for the constitutions of many states of the world community. Along with the national, moral and ethic values, the Constitution of the Republic of Azerbaijan co-opted national and universal human priorities. Rights and freedoms of a human being and citizen in the Constitution of the Republic of Azerbaijan found their rightful place and became a basis for the building of democratic civil society.

\section{References}

Committee on Crime problem. (1990). Publishing and Documentation Service, 112. Strasbourg.

Constitution of the Republic of Azerbaijan. (2005). Baku General Declaration of human rights. In Bioethics: 
documents, term. Baku.

Kudrna, J. (2012). Human rights - real of the just formal rights? Example of the (UN) constitutionality of data retention in the Czech Republic. Jurisprudence, 19(4), 1289-1300.

Mullerson, P. (1980). National-legal implementation of international treaties. Annual of the International law. Moscow.

Official reports of the UN General Assembly, session 34. Supp. No.46, 250-254. Retrieved from http://ru.wikisource.org/w/index.php/title/728433

Official reports of the UN General Assembly, session 44. Supp. No.49 (A/44/49), 230-239. Retrieved from http://ru.wikisource.org/w/index.php/title/728433

UN Documents.144/7, pg.7-8; A/46/346.Add.2, p. 2

United Nations Treaty Series, vol.660, 240-266. Retrieved from http://un.org/documents/decl_conv/conventions/pactpol/shtml

United Nations Treaty Series, vol.993, 35. Retrieved from http://un.org/documents/decl_conv/conventions/pactpol/shtml

United Nations Treaty Series, vol.999, 225. Retrieved from http://un.org/documents/decl_conv/conventions/pactpol/shtml

Vitkauskaite-Meurice, D. (2010). The Arab charter declaration of human rights: the naissance of new regional declaration of human rights system or a challenge to the universality declaration of human rights? Jurisprudence, 1(119), 165-180.

\section{Copyrights}

Copyright for this article is retained by the author(s), with first publication rights granted to the journal.

This is an open-access article distributed under the terms and conditions of the Creative Commons Attribution license (http://creativecommons.org/licenses/by/3.0/). 